\title{
Significant Persons
}

Chapter 2

Samiullah Safi

Son of Sultan Muhammad Khan and narrator of the story recounted at the beginning of chapter 2

Sultan Muhammad Khan Son of Talabuddin Akhund-

Talabuddin Akhundzada zada, the hakim of Pech Valley The hakim of Pech Valley who is killed in the story recounted at the beginning of chapter 2

'Ali Dost Talabuddin Akhundzada's brother

Paindo

Talabuddin Akhundzada's cousin and rival who (along with his seven sons) is blamed for killing Talabuddin

Faizullah Paindo's brother (unnamed in story)

Chapter 3

Abdur Rahman Khan

King of Afghanistan from $188 \mathrm{o}$ to 1901

Dost Muhammad Grandfather of Abdur Rahman Khan and king of Afghanistan (1819-39; 1842-63) 
Muhammad Afzal Khan

Muhammad Azam Khan

Sher 'Ali Khan

Muhammad Isaq Khan

\section{Chapter 4}

Mulla of Hadda

Akhund of Swat (Abdul Ghafur)

Abdul Baqi

Hazrat Sahib of Butkhak

Sufi Sahib of Batikot (and Faqirabad)

Mulla Sahib of Kajuri

Sayyid Ismail Pacha of Islampur

Haji Sahib of Turangzai

Ustad Sahib of Hadda
Son of Dost Muhammad Khan, father to Abdur Rahman, and king of Afghanistan (1866-67) Eldest son of Dost Muhammad, full brother of Muhammad Afzal, and king of Afghanistan (1867-69)

Son of Dost Muhammad, half brother of Muhammad Afzal and Muhammad Azam, father of Muhammad Isaq Khan, and king of Afghanistan (1863-66; 1869-79)

Son of Muhammad Azam and rival to Abdur Rahman Khan

Major religious figure in Afghanistan in the late nineteenth century. Born Najmuddin Akhundzada, he is also referred to in various stories and accounts as Hadda Sahib, the Hadda Mulla, and Mulla Najmuddin.

Teacher of the Mulla of Hadda and the progenitor of the mianguls of Swat, one line of which became the ruler (wali) of Swat Attendant of the Mulla of Hadda

Disciple of the Mulla of Hadda Disciple of the Mulla of Hadda Disciple of the Mulla of Hadda Disciple of the Mulla of Hadda Disciple of the Mulla of Hadda Disciple of the Mulla of Hadda and heir to the center at Hadda 
Shaykh Sahib of Sangar

Mia Sahib of Baro

Mulla Sahib of Tagao

Manki Mulla
Disciple of the Mulla of Hadda

Disciple of the Mulla of Hadda

Disciple of the Mulla of Hadda

Religious scholar who was the

Mulla of Hadda's principal rival on the frontier 


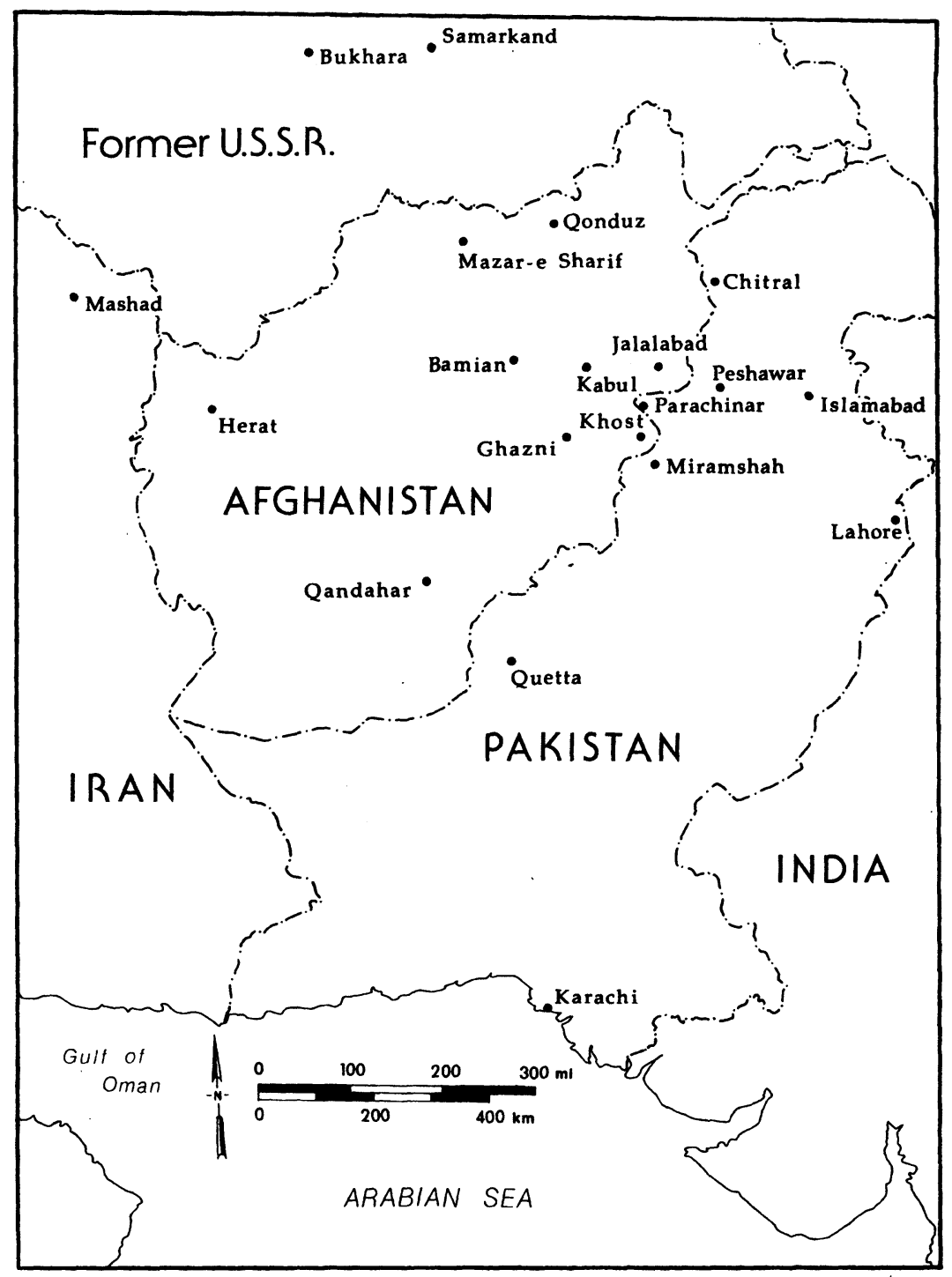

Map 1. Afghanistan 


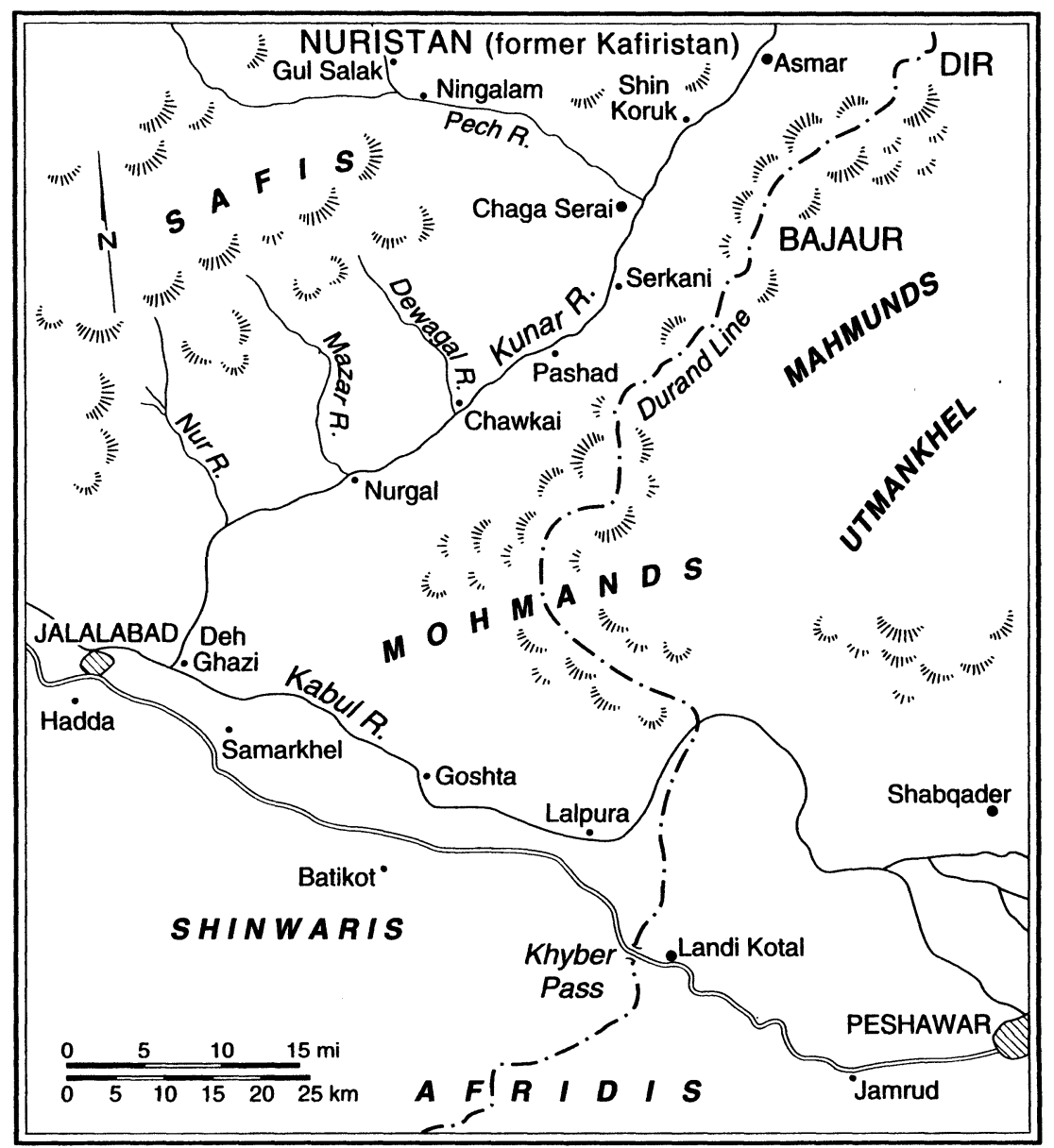

Map 2. Eastern Afghanistan and the north-west frontier of Pakistan 
This page intentionally left blank 